\title{
Microbial contamination of procedure gloves after opening the container and during exposure in the environment*
}

\author{
CONTAMINAÇÃO MICROBIANA DAS LUVAS DE PROCEDIMENTO APÓS A ABERTURA \\ DA CAIXA E DURANTE SUA EXPOSIÇÃO AMBIENTAL
}

CONTAMINACIÓN MICROBIANA DE GUANTES DE PROCEDIMIENTO LUEGO DE LA
ABERTURA DE LA CAJA Y DURANTE EXPOSICIÓN AMBIENTAL

Adriano Menis Ferreira ${ }^{1}$, Denise de Andrade², Vanderlei José Haas ${ }^{3}$

\begin{abstract}
The objective of this study was to quantify the colony forming units (cfu) on latex procedure gloves in the beginning, middle, and end of the containers in real (professional) and controlled (researcher) gloving situations; evaluate the microbial load of the gloves, considering the time of exposure in the environment. This comparative prospective study was conducted at an intensive care unit of a teaching hospital. The microbiological data was collected from the gloves using digital-pressure. Microbiological evaluations were performed on 186 pairs of gloves: 93 in the control group and 93 in real gloving situations. In the control group, the average cfu was 4.7 against 6.2 in the real gloving situation. Hence, no statistically significant difference was found ( $p=.601)$. In addition, the cfu values of gloves in the beginning, middle and end of the containers also did not show any significant differences ( $p>.05)$. The most common strain was Staphylococcus spp. The time of exposure in the environment did not increase the cfu value of the latex gloves.
\end{abstract}

\section{DESCRIPTORS}

Gloves, surgical Intensive Care Units

Cross infection

\begin{abstract}
RESUMO
Este trabalho teve como objetivo quantificar as Unidades Formadoras de Colônias (ufc) das luvas de látex para procedimentos no início, meio e fim das caixas na situação real (profissional) e controle (pesquisador) de enluvamento; avaliar a carga microbiana das luvas considerando o tempo de exposição ambiental. Trata-se de um estudo comparativo e prospectivo realizado em uma unidade de terapia intensiva de um hospital-escola. A coleta das amostras microbiológicas das luvas foi realizada por meio da digito-pressão. Avaliaram-se microbiologicamente 186 pares de luvas, 93 no grupo controle e 93 na situação real de enluvamento. No grupo controle a média de ufc foi de 4,7 e na situação real de enluvamento 6,2 , consequentemente, não houve diferença estatisticamente significante $(p=.601)$. Também, as ufc no inicio, meio e fim das caixas não se observou diferenças significante $(p>05)$. A cepa Staphylococcus spp. foi a mais freqüente. O tempo de exposição ambiental das luvas de látex não determinou aumento de ufc.
\end{abstract}

\section{DESCRITORES}

Luvas cirúrgicas

Unidades de Terapia Intensiva

Infecção hospitalar

\section{RESUMEN}

Trabajo que objetivó cuantificar las Unidades Formadoras de Colonias (UFC) en guantes de látex para procedimientos al inicio, mitad y final de las cajas en situación real (profesional) y control (investigador) de uso de guantes: evaluar carga microbiana de guantes considerando tiempo de exposición ambiental. Estudio comparativo prospectivo realizado en unidad de terapia intensiva de hospital-escuela. La recolección de muestras microbiológicas de guantes se realizó mediante dígito presión. Se evaluaron microbiológicamente 186 pares de guantes, 93 en grupo control y 93 en situación real de uso. En grupo control, la media de UFC fue de 4,7 y en situación real 6,2. Consecuentemente, no hubo diferencia estadísticamente significativa $(p>0,601)$. Tampoco se observó diferencia significativa de UFC en comienzo, mitad y final de cajas $(p>0,05)$. La cepa Staphylococcus spp. fue la más frecuente. El tiempo de exposición ambiental de los guantes de látex no determinó aumento de UFC.

\section{DESCRIPTORES}

Guantes quirúrgicos

Unidades de Terapia Intensiva

Infección hospitalaria

\footnotetext{
* Extraído da tese "Avaliação da segurança microbiológica das luvas de látex para procedimentos em uma Unidade de Terapia Intensiva", Escola de Enfermagem de Ribeirão Preto, Universidade de São Paulo, 2007. ${ }^{1}$ Enfermeiro. Professor Doutor do Departamento de Enfermagem da Úniversidade Federal de Mato Grosso do Sul. Três Lagoas, MS, Brasil. a.amr@ig.com.br ${ }^{2}$ Enfermeira. Professora Livre Docente do Departamento de Enfermagem Geral e Especializada da Escola de Enfermagem de Ribeirão Preto da Universidade de São Paulo. Centro Colaborador da Organização Mundial da Saúde para o Desenvolvimento da Pesquisa em Enfermagem. Ribeirão Preto, SP, Brasil. dandrade@eerp.usp.br ${ }^{3}$ Doutor em Física e Pós-Doutor na Área de Estatística. Ribeirão Preto, SP, Brasil.vjhaas@uol.com.br
} 


\section{INTRODUÇÃO}

The use of latex gloves is considered an effective resource for health care workers safety against exposure to body fluids and their use is a practice most easily conducted in everyday practice, and thus avoids contamination to patients, materials, and the environment. Therefore, gloves are recommended in clinical practice in activities involving biological risks, such as venous punctures, intravenous medication administration, managing dressings, insertion of enteral feeding tubes, managing contaminated material such as clothes, and other procedures ${ }^{(1-4)}$.

The wide range of procedures associated with biological risk and cross-infection are among the factors that have made it difficult to choose the most appropriate glove. For this reason, studies ${ }^{(4-12)}$ about the use of procedure and sterile gloves remain contradictory from a microbiological safety viewpoint. In this sense, the indication of wearing procedure gloves in certain activities and preferring them to sterile gloves need further studies. Consequently, there are gaps regarding the microbiological safety of gloves from the beginning to the end of the box.

The hands of healthcare workers can be highly contaminated, especially during routine care procedures when they are exposed to body fluids. In addition to hand hygiene, nonsterile gloves are an important tool in minimizing cross-transmission of microorganisms from one patient to another. However, healthcare workers must be aware that nonsterile disposable gloves could be contaminated with a wide range of bacteria ${ }^{(3)}$. Because bacteria can survive for several months in the environment and because nonsterile disposable gloves are widely used for care procedures involving mucosa ${ }^{(13)}$ and as the Brazilian manufacturing standards for nonsterile gloves only require physical testing, guidelines and quality norms on bacterial contamination of disposable gloves are needed.

Little information is available regarding microbial contamination of open box gloves before and during use. To our knowledge, this study is the first in Brazil to have investigated the bacterial contamination of nonsterile disposable gloves in the hospital setting.

\section{OBJECTIVES}

Based on these considerations, this comparative, prospective study aimed to quantify Colony Forming Units (cfu) on procedure latex gloves at the beginning, middle and end of boxes in real situation and gloving control, and to evaluate the microbial load of the gloves considering the environment exposure time in an intensive care unit setting.

\section{METHOD}

This is a comparative and prospective study, performed at the intensive care unit (ICU) of the Clinics Hospital, the University of São Paulo at Ribeirão Preto College of Medicine. The study was approved by the hospital's Research Ethics Committee protocol 0638/2005.

The gloves used in this study were commercially available EMBRAMAC ${ }^{\circledR}$ powdered disposable gloves latex, recommended for hospital use and packaged in boxes of 100 units. The evaluation was performed using the technique of digit-pressure on Petri dishes with Mueller Hinton (MH) agar. A total of 31 boxes of procedure gloves were employed. The boxes were labeled with the date, time of opening, and numbered from 1 to 31 . The boxes were kept in counters with openings and disposed in places that were easy to see and access, to ensure that all gloves were obtained exclusively from the test-boxes.

The researcher opened the boxes, used for both control group and real health care situations, after performing adequate hand disinfection and wearing sterile gloves. This procedure was performed to avoid contamination of the gloves while opening them. Therefore, when collecting control samples (beginning, middle, and end of boxes), the researcher wore sterile gloves under the procedure gloves. The fingertips of each gloved digit was placed on Petri dishes employing light pressure. After digit-pressure of the control-situation, the researcher removed the gloves and waited for the moment to collect samples from the gloves used by a health worker (real health care situation). The sample was collected respecting the demand of health care activities requiring glove use. This helped to preserve the reality of glove use in daily clinical practice. After the health worker gloved his or her hands, they were asked permission to collect the samples by digit-pressure of their right and left hands on separate Petri dishes and in different moments (beginning, middle, and end of boxes). To estimate the cfu on ungloved hands, digit-pressure was performed on nine health workers before they gloved their hands.

After collecting the samples, the Petri dishes (150mm) were stored in a polystyrene box and taken to the microbiology lab. The plates were incubated at $35^{\circ} \mathrm{C}$ for 48 hours under aerobic condition. After incubation each plate was inspected (counted cfu), in a class II microbiological safety cabinet to exclude airborne contamination, using a stereoscopic microscope under reflected light. The microorganism were then identified following a previously described $\operatorname{method}^{(5)}$.

Statistical Package for the Social Science - SPSS 15.0 software was used to analyze and compare the data. To compare CFU numbers, analysis of variance (ANOVA) was used 
with repeated measures and a same factor (within subject factor). The contamination rate of the gloves according to the different moments and exposure time was analyzed by means of the Cochrane non-parametric test, with level of significance at $\alpha=0.05$. The association between time of box opening and number of cfu, in either the control-situation or real gloving situations, was measured by the Spearman's rank correlation coefficient (level of significance at $\alpha=0.05$ ).

Calculating the size of the sample in an analysis of variance (ANOVA) with repeated measures for 6 comparisons is a complex procedure. However, a power analysis was carried out a posteriori and it was observed that, to detect a within-subject effect statistically significant $(p=0.02)$ in the 6 comparisons done for $n=31$ boxes, the observed Power was of 0.728 , applying Greenhouse-Geisser correction. Despite this effect, no statistically significant difference was detected applying Bonferroni correction for multiple comparisons.

\section{RESULTS}

The bare hands of nine health workers revealed a $100 \%$ rate of contamination and a mean of $263 \mathrm{cfu}$.

A total of 186 pairs of gloves were obtained, 93 from control gloves and 93 from real health care situations, i.e., from the workers' clinical practice. The contamination rate was $88.2 \%$ for the control group and $87.1 \%$ in real situations, showing an increase in $1.1 \%$. Of the gloves used in the control-situation, 82 pairs were contaminated, against 81 pairs in the real or routine situation. The mean colony density was 4.7 (SD 4.1) in the control group, and 6.2 (SD 4.9) in the real situation group, showing an average increase of 4.95 colonies per box.

Table 1 displays the number of colonies on the gloves in the beginning, middle, and end in the 31 boxes for the real and control situations.

Table 1 - Central tendency and variability of Colony Forming Units (CFU) for the pairs of gloves with and without colonies, according to their position in the 31 boxes (begining, middle, end) in real and control situations - Ribeirão Preto - 2007

\begin{tabular}{|c|c|c|c|c|c|c|c|c|c|}
\hline & \multicolumn{2}{|c|}{ Positive } & \multicolumn{2}{|c|}{$\begin{array}{c}\text { Absence of } \\
\text { growth }\end{array}$} & \multicolumn{5}{|c|}{$\begin{array}{l}\text { Identified Collonies } \\
\text { (cfu) }\end{array}$} \\
\hline & $\mathbf{N}$ & $\%$ & $\mathbf{N}$ & $\%$ & Minimum & Maximum & Median & $\mathbf{X}$ & SD \\
\hline \multicolumn{10}{|l|}{ Beginning } \\
\hline Control (n=31) & 29 & 93.5 & 2 & 6.5 & 1 & 53 & 5 & 7.64 & 10.4 \\
\hline Real situation ( $\mathrm{n}=31$ ) & 28 & 90.3 & 3 & 9.7 & 1 & 64 & 6 & 9.83 & 5.0 \\
\hline \multicolumn{10}{|l|}{ Middle } \\
\hline Control $(\mathrm{n}=31)$ & 28 & 90.3 & 3 & 9.7 & 1 & 12 & 2 & 3.0 & 3.11 \\
\hline Real situation $(\mathrm{n}=31)$ & 26 & 83.9 & 5 & 16.1 & 1 & 14 & 2 & 3.4 & 3.46 \\
\hline \multicolumn{10}{|l|}{ End } \\
\hline Control $(\mathrm{n}=31)$ & 25 & 80.6 & 6 & 19.4 & 1 & 18 & 3 & 3.58 & 3.94 \\
\hline Real situation $(\mathrm{n}=31)$ & 27 & 87.0 & 4 & 13.0 & 1 & 34 & 3 & 5.35 & 7.15 \\
\hline
\end{tabular}

Table 1 show that the contamination density of the 186 pairs of gloves (31 pairs in each of the six conditions) did not exceed 64 colonies. Despite the high contamination rate (93.5\% in the control group, and $90.3 \%$ in real situation), bacteria density was relatively low. In general, it is noticed that the cfu did not present a significant variability, which is shown by the obtained standard-deviation values.

The Cochran Test revealed no statistically significant difference $(p=0.601)$ regarding the boxes' contamination rate between the control and real situation, as well as in the different moments (beginning, middle, and end).

In the control situation, the correlation between the contamination of the first pair of gloves and the pair in the middle of the box was not significant $(p=0.327)$. The result remained the same between the first and last pairs $(p=0.687)$, as well as between the middle and the last pairs $(p=1.000)$. In the situation of routine glove use, the correlations between beginning, middle, and end of the boxes showed no statistically significant differences $(p=0.262$; $p=1.000$, and $p=1.000$, respectively).
The contamination rate of gloves in the control situation, in the beginning, middle, and end of the box was $93.5 \%, 90.3 \%$ and $80.6 \%$ respectively. However, the contamination density means were $7.64,3.0$ and $3.58 \mathrm{cfu}$. Similar contamination rate results were observed in the real donning situation: $90.3 \%, 83.87 \%$, and $87.08 \%$ under the same circumstances. The mean contamination density was 9.83; 3.4, and $5.35 \mathrm{cfu}$. From a global perspective, the statistical tests point out that the contamination rates are not significant in the three positions of the gloves in the boxes.

Regarding the boxes' time of exposure, there was no correlation with the presence or absence of contamination of the last pair of gloves. In six boxes in which the last pair of gloves (control) did not show any microbial growth, the boxes remained open for an average of 5.8 hours (SD 1.68). In 25 boxes in which the last pair was colonized, the average time opened was 6.24 hours (SD 1.57).

In the real donning situation, four pairs did not present microbial growth and the boxes remained open for an average of 6.57 hours (SD 1.78). The other 27 pairs of gloves that 
showed microbial growth were exposed for an average of 6.10 hours (SD 1.57). The correlation between time of box opening and contamination density was $-0.12(p=0.49)$.

Regarding the time that the boxes remained opened, (mean 6.3 hours) there was no correlation with the increase in the number of colonies in the last pairs of gloves in either the control or real situations. Using simple logistic regression, there is no statistically significant relation for the association between time of box opening and the occurrence of colonization in the control $(p=0.572)$ and in the real $(p=0.576)$ donning situation.

The predominant microorganism $(>90 \%)$ on the plates was Staphylococcus spp.

\section{DISCUSSION}

In accordance with standard precautions, the use of disposable gloves followed immediately by hand hygiene after removal is intended to minimize cross transmission of microorganisms in the hospital setting. Therefore, it is recommended that health care workers wear gloves in a range of procedures that involve contact with mucosa and secretions ${ }^{(13)}$.

The latex procedure gloves are stored in individual boxes and used during health care activities. The boxes remain open for several hours and are handled by different workers.

Another issue that emerges in this setting refers to removing gloves from the box. Even when hands have been disinfected, there still is a possibility of transferring native hand microbiota to the gloves that will be used in clinical practice as well as to those that remain in the box. Empirically, it was observed that the workers rarely touch only the gloves they will use. In addition, low compliance to hand disinfection by health care workers can increase this contamination even more.

Even if a box of gloves is designated to a single patient or bed, it is still subject to being handled by different members of the health team, each with different methods of hand disinfection, if any. In addition, since these workers look after more than one patient, these boxes can function as reservoirs of microorganisms and cause cross contamination between workers and patients.

This fact can explain the results found in this study, which showed that, despite rigorous aseptic technique (control situation) when opening the boxes and donning gloves, there was a high contamination rate, although it was not significant. One possible explanation for this fact would be the external contamination of the box when removing the first pair of gloves; the worker could touch the box surface and contaminate the gloves. Other explanations would be that contamination of these gloves occurred during manufacture process ${ }^{(14)}$, low adherence to hand hygiene or, still, environmental contamination, since the gloves are exposed to the surrounding air after the opening in mean 6.3 hours.
Health workers, themselves, have been pointed as microorganism reservoirs and disseminators, of either their microbiota to the patient, or the patient's microbiota to themselves, or, yet, as a vehicle of transmission between patients. In the chain of transmission, the health workers' role represents a challenge that has been historically recorded in national and international literature ${ }^{(15)}$. The health worker's hands are recognized as one of the main elements in the chain of transmission. With their hands, workers provide care, touch different surfaces, and handle material that could be colonized by numerous microorganisms.

Since the 1980s, this issue has been the object of several studies, which demonstrate that the hands of health team members could be contaminated with $S$. aureus before routine procedure glove use, with a mean of $1 \times 10^{4}$ cfu. Of the nurses working in a general hospital, $29 \%$ had these microorganisms on their hand (median: $3.8 \times 10^{2}$ ), while $78 \%$ who worked in hospitals with dermatology patients had this agent on their hands with a median of 14.3 $x 10^{6} \mathrm{cfu}^{(16)}$.

The results from this study show a low number of isolated cfu on procedure gloves donned in real conditions (mean of $6.2 \mathrm{cfu}$ ). It should be stressed that the workers seldom disinfected their hands before donning the gloves ${ }^{(15-16)}$. Although this variable was not evaluated in this study, the non-systemized observations revealed that a considerable part of the workers did not disinfect their hands, though there was alcohol gel and sinks in strategic locations. It cannot be stated, however, that the lack of compliance to hand disinfection affected the microbial rate and density recovered from the procedure gloves in the real donning situation.

Based on the results of this study, it is recommended that procedure gloves be rationally used as long as asepsis measures are preserved. Hence, using procedure gloves in health care requires reflection and decision making.

Another issue that emerges in this setting is the identification of the isolated microorganism on the gloves. In this sense, epidemiologic studies stress that staphylococcus are the causers of hospital infection, which are historically pointed out as one of the main agents. Its importance is also linked to the fact that they are skin and mucosa colonizers, which are the main physiological protection barrier of internal organs. Besides composing the native hand and mucosa microbiota, Staphylococcus spp. is also an important element of the transitory microbiota ${ }^{(17)}$. In addition, about $30 \%$ of the individuals, though healthy, bear these bacteria in their nostrils. A lower percentage bears bacteria in other body parts, such as the axillas, the inguinal region, perineum, and vagina. Some individuals can bear an even greater load of these microorganisms, due to an impaired defense system. Examples of these individuals are diabetic patients, patients subjected to dialysis, and those with skin diseases among other aliments ${ }^{(17-18)}$.

It has already been shown that disposable gloves can be contaminated and that gloves made of nitrile are significantly 
more contaminated with bacteria than those made of latex or polyvinyl ${ }^{(3)}$. From a global view of the literature ${ }^{(3-8,12,19-20)}$, the gene Staphylococcus has been reported as the most prevalent microorganism on procedure gloves and their boxes.

A study ${ }^{(6)}$, similar to ours, had the objective of identifying the type, rate burden, and pattern of contamination of boxed, clean, nonsterile gloves in an intensive care unit. The researchers found that 16 of 29 (55\%) first pairs of gloves removed aseptically (control-situation) from boxes were contaminated, with a mean bioburden of 1.8 colony-forming units (cfu). The percentage contamination and bioburden did not change significantly with the glove's position in the box. There was only an $11 \%$ increased in the rate of contamination when gloves were removed without special precautions (real health care situation) compared with controlsituation. The length of time that boxes were open and being used was unrelated to whether the final, aseptically removed pair was sterile or contaminated. Those gloves that were contaminated had an extremely small bioburden and conclude that boxed, clean, nonsterile gloves appears to be safe for routine use in the intensive care setting.

Compared to the anterior study, our results have shown greater contamination of the first pairs of gloves asseptically removed (control group), 82 of 31 (88.2\%) pairs. The contamination rate (pairs with less than $1 \mathrm{cfu}$ ) was of $88.2 \%$ in control and $87.1 \%$ in the real situation, showing a $1.1 \%$ raise.

Another study ${ }^{(20)}$ evaluated a sample of open box gloves found in labour and delivery as potential fomites. A representative glove was sampled from in-use boxes from ten labour and delivery rooms. The gloves were removed with sterile forceps and placed in a sterile specimen bag. Sterile

\section{REFERENCES}

1. Oliveira AC, Cardoso CS, Mascarenhas D. Contact precautions in Intensive Care Units:_facilitating and inhibiting factors for professionals' adherence. Rev Esc Enferm USP [Internet]. 2010 [cited 2010 Feb 13];44(1):161-5. Available from: http:// www.scielo.br/pdf/reeusp/v44n1/en_a23v44n1.pdf

2. Girou E, Chai SHT, Oppein F, Legrand P, Ducellier D, Cizeau F, et al. Misuse of gloves: the foundation for poor compliance with hand hygiene and potential for microbial transmission? J Hosp Infect. 2004;57(2):162-69.

3. Berthelot P, Dietemann J, Fascia P, Roset A, Mallaval FO, Lucht $F$, et al. Bacterial contamination of nonsterile disposable gloves before use. Am J Infect Control. 2006;34(3):128-30.

4. Sadowski DA, Polman S, Maley MP, Warden GD. Use of no sterile gloves for routine invasive procedures in thermally injured patients. J Burn Care Rehabil .1998;9:613-5.

5. Burke FJT. Use of non-sterile gloves in clinical practice. J Dent. 1990;18(2):79-89. broth medium was then poured into the bag and the fluid was agitated around all surfaces of the glove. The sampled glove was then removed and the fluid incubated. The open box glove results showed that nine out of ten open box gloves sampled were contaminated with bacteria, none of which were of high virulence, only common environmental bacteria, being the bacterial specie coagulase-negative Staphylococcus (CNS) the most frequent. Conclude that the bacteria found on the open box gloves are certainly less virulent than the bacteria commonly found in the vagina.

Studies ${ }^{(4-12,14-15,18)}$ have shown that researchers correlate latex procedure gloves with sterile gloves in cases of infection, and there appears to be no correlation as long as manufacturing, maintenance, and use policies are preserved. Although procedure gloves host bacteria, it appears they are not sufficient to trigger infection when used in the various health care procedures.

\section{CONCLUSION}

In summary, latex procedure gloves used in an ICU of a General Teaching Hospital showed low microorganism density. It is worth recalling that, after opened, the glove boxes remain exposed to the contact of different workers as well as to the environment. It is emphasized that the time of exposure of the gloves did not cause significant contamination comparing the beginning, middle, and end of the box. As glove sampling occurred without the staff having been warned, and the rooms from which the gloves were sampled were in active use, it is highly probable that our results reflect typical use. Therefore, the use of procedure gloves appears to be safe from the microbiological viewpoint.

6. Rossoff LJ, Lam S, Hilton L, Borenstein M, Isenberg HD. Is the use of boxed gloves in an intensive care unit safe? Am J Med. 1993;94(6):602-7.

7. Giglio JA, Rowland RW, Laskin DM, Grenevicki L, Roland RW. The use of sterile versus nonsterile gloves during out-patient exodontia. Quintessence Int. 1993;26(8):533-34.

8. Cheung LK, Chow LK, Tsang MH, Tung LK. An evaluation of compications following dental extractions using either sterile or clean gloves. Int J Oral Maxillofac Surg. 2001;30(6):550-54.

9. Lawson C, Juliano L, Ratliff CR. Does sterile or nonsterile technique make a diference in wound healing by secondary intention? Ostomy Wound Management. 2003;29(10):56-60.

10. Perelman VS, Francis GJ, Rutledge T, Foote J, Martino F, Dranitsaris G. Sterile versus nonsterile gloves for repair of uncomplicated laceration in the emergency department: a randomized controlled trial. Ann Emerg Med. 2004;43(3): 362-70. 
11. Adeyemo WL, Ogunlewe MO, Ladeinde AL, Bamgbose BO. Are sterile gloves necessary in nonsurgical dental extractions? J Oral Maxillofac Surg. 2005;63(7):936-40.

12. Chiu WK, Cheung LK, Chan HC, Chow LK. A comparison of post-operative complications following wisdom tooth surgery performed with sterile or clean gloves. Int J Oral Maxillofac Surg. 2006;35(2):174-79.

13. Pittet D, Allegranzi B, Boyce J; World Health Organization World Alliance for Patient Safety First Global Patient Safety Challenge Core Group of Experts. The World Health Organization Guidelines on Hand Hygiene in Health Care and their consensus recommendations. Infect Control Hosp Epidemiol. 2009;30(7):611-22.

14. Luckey JB, Barfield RD, Eleazer PD. Bacterial count comparisons on examination gloves from freshly opened boxes versus nearly empty boxes and from examination gloves before treatment versus after dental dam isolation. J Endod. 2006;32(7):646-48.
15. Rhinehart BM, Murphy ME, Farley MF, Albertini JG. Sterile versus nonsterile gloves during mohs micrographic surgery: infection rate is not affected. Dermatol Surg. 2006;32(2):170-6.

16. Ayliffe GA, Babb JR, Davies JG, Lilly HA. Hand disinfection: a comparison of various agents in laboratory and ward studies. J Hosp Infect. 1988;11(3):226-43.

17. Tang YW, Stratton CW. Staphylococcus aureus: an old pathogen with new weapons. Clin Lab Med. 2010;30(1):179-208.

18. Giglio JA, Rowland RW, Laskin DM, Grenevicki L, Roland RW. The use of sterile versus nonsterile gloves during out-patient exodontia. Quintessence Int. 1993;24(8):543-5.

19. Rossoff $L J$, Borenstein $M$, Isenberg HD. Is hand washing really needed in an intensive care unit ? Crit Care Med. 1995;23(7): 1211-6.

20. Jackson S, Morgan M, Nichols S, Shay A, Kim M. Are open box gloves clean enough to perform vaginal examinations? J Hosp Infect. 2010;75(3):243-44. 